（昭和 33 年 11 月造船協会秋季講演会に於て講演）

\title{
船の操縦性指数について
}

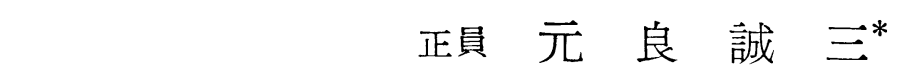

On the Manoeuverability Index of Ships

By Seizo Motora, Member

Abstract

The Author states in this paper following results out of his research including two actual ship experiments ;

(1) The equation of motion of ships under steering can be reduced to a differential equation of 1 st stage as follows.

$$
T_{s} \frac{d \dot{\theta}}{d t}+\dot{\theta}=K_{s} \delta
$$

where $T_{s}$ is a constant which represents the quick responsibility of ships, and

$K_{s}$ is a constant which represents the turning quality.

'Though, $T_{s}$ and $K_{s}$ will both vary with the curvature of the locus of ships, according to some experiments, the amount of variation is thought to be not so large.

(2) The ratio $K_{s} / T_{s}$ is a constant, i e,

$K_{s} / T_{s}=$ rudder turning moment/moment of inertia of the ship $\times$ rudder angle.

and is easily calculated when the dimensions of the ship and rudder are given.

So we can get $K_{s}$ and $T_{s}$ when either one is given.

(3) It will be most reasonable to get $K_{s}$ from data of steady turning experiment, i e,

$$
K_{s}=\dot{\theta}_{s} / \delta
$$

where $\dot{\theta}_{s}$ is the angular velocity of steady turning

(4) $T_{s}, K_{s}$ will both vary with the curvature of the locus of ship's C. G., i e. stronger the curvature, larger the both $K_{s}$, and $T_{s}$, in other wards, smaller the radius of turning, better the quick responsibility and worse the turning quality. But, the amount of variation is thought to be so small that we can get a close approximation of turning angle curve from initial stage to final stage using $T_{s}$ and $K_{s}$ got from the steady turning data.

緒言

船の操縦運動に対する運動方程式は, 回転角速度と横すべりの速度との連立方程式となり, 非線型影響を無視 乙てもな打回転角速度に関する二階微分方程式となり，その解の形は船の操綎性能と直接結びつけるには複雑す ぎて不便である。

野本氏等 ${ }^{(3)(4)(5)(6)}$ は船の操縦運動は本質的に回転角速度の一階微分方程式で近似出来るものである事を示し, 旋回性能を表わす常数 $K$ と，追従性及び保針性を表わす常数 $T$ とにより，船の総合的な操緃性能が表わされ るとして，これを操縦性指数と名づけた。野本氏等は更にこの $T$ と $K$ を $z$ 操舵試験を解折することにより求 める巧妙な方法を考案して，従来極めて莫然としていた保針性と旋回性との関連を含む船の総合的な操縦性能を 明確に表わすことに成功した。

しかしながらこの $z$ 試験より求められた $T$ と $K$ は 1 次系近似による種々の誤差や非線型影響をすべて含ま せてあるため，極めて実用的な反面，従来擦縦性を表わすのに用いた旋回半径の様な単純な值と直接には結び つかない。例えば $K$ は旋回性を表わす常数で $K \delta$ が旋回角速度を表わすが，定常旋回の角速度そのものではな

原稿受付. 7 月 15 日

* 東京大学工学部船舶工学科教室 
く，定常旋回を表わすためには，多少の修正を要するし，保針性を表わす $T$ も保針性そのものではない。

操縱性指数を直進時の保針性と定常旋回円の大きさに直接結びつけることは船の操総性を表わすとい5目的か らは必ずしも必要ではないが, 従来操緃性の目安とされて来たこれらの值を用いて船の操絑性が総合的に表わさ れれば便利であることは論を俟たない。

筆者は運動方程式を pivoting point の周わりの運動に変形することにより完全に 1 次系に変形しらることと， さらに定常旋回時の角速度または旋回円の大きさを知ることによつて簡単に操䋛性指数を求めらることを発見し たのでここに発表して大方の御批判を乞う次第である。

\section{1 運動方程式の変形}

\section{1 運動方程式}

船の操舵に対する運動方程式は，船に固定した座標系に対して次の如くなる(1)（第1図）。

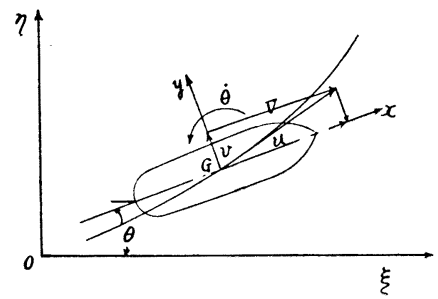

第 1 図

$$
\begin{aligned}
& \frac{d v}{d t}=k_{1} v+k_{2} \dot{\theta}+k_{p} \cdot \delta \\
& \frac{d \dot{\theta}}{d t}=f_{1} v+f_{2} \dot{\theta}+k_{n} \cdot \delta
\end{aligned}
$$

ただし $v$ は横すべりの速度

$k_{p} \cdot \delta=$ 舵の偏力 $/ \mathrm{m}+\mathrm{my}$

$\delta=$ 舵角

$m_{y}=y$ 方向の見掛質量

$J_{z}=$ 見掛の慣性モーメント

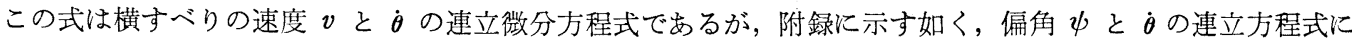
も容易に変換出来る。

（1）式の解を求めるには通常 $2 つ$ 式より $v$ を消去して $\dot{\theta}$ に関する二階の微分方程式にする。即ち :

$$
\frac{1}{k_{1} f_{2}-k_{2} f_{1}} \frac{d^{2} \dot{\theta}}{d t^{2}}-\frac{f_{2}+k_{1}}{k_{1} f_{2}-k_{2} f_{1}} \frac{d \dot{\theta}}{d t}+\dot{\theta}=\frac{k_{p} f_{1}+k_{1} k_{n}}{k_{1} f_{2}-k_{2} f_{1}} \delta+\frac{1}{k_{1} f_{2}-k_{2} f_{1}} \frac{d \delta}{d t}
$$

野本氏等はこの式を

$$
T_{1} \cdot T_{2} \frac{d^{2} \dot{\theta}}{d t^{2}}+\left(T_{1}+T_{2}\right) \frac{d \dot{\theta}}{d t}+\dot{\theta}=K \delta+K T_{3} \frac{d \delta}{d t}
$$

と置き $T_{1}, T_{2}, T_{3}$, 及び $K$ を正弦操舵に対する応答より求める方法を示し(3)，さらに $T_{1} \gg T_{2}$ であることに着 目して (3) 式を

$$
T \cdot \frac{d \dot{\theta}}{d t}+\dot{\theta}=K \delta
$$

なる1次系で近似して，T及び $K$ を $\boldsymbol{z}$ 操舵試験より求める方法を考案したわけである(4)(5)(6)。

\section{2 操舵運動に対する pivoting point の位置}

第 2 図の如く, 角速度 $\dot{\theta}$, 横すべり速度 $v$, 偏角 $\psi$ で運動中の船 では, 重心より

$$
l p=-\frac{V \psi}{\dot{\theta}}=-\frac{v}{\dot{\theta}}
$$

で与えられる距離丈前では, 水流は船体中心線に平行となり, 偏角が 見掛上 0 となることはよく知られて居り，この点を pivoting point (転心) と称する(8)。

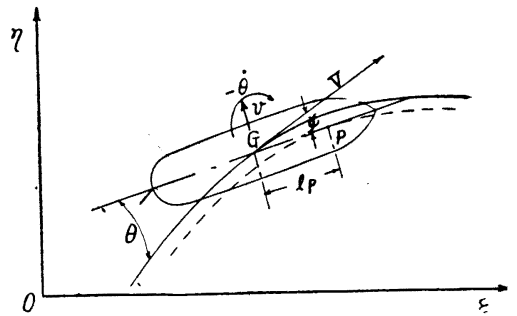

第 2 図

直進中操舵した僢間には慣性力のみが影響するので，赤崎氏 ${ }^{\left({ }^{8}\right)}$ が指摘する様に，pivoting point は舵の位置に 衝撃を加光た時の撃心に相当する。この位置は普通の船型に対してほぼ $l_{p}=0.2 L \sim 0.25 L$ 位になる。

旋回が進んで $v$ 及び $\dot{\theta}$ が有限になつて来た時の $l_{p}$ は例之ば文献 1) のS·3 船型について計算すれば第 3 図 の如くなり角速度の増加と共飞徐々に前に寄り，定常状態ではほぼ $l_{p}=0.4 L \sim 0.45 L$ 位となるが，この間急 激な変化は認められない。

\section{3 pivoting point を中心とする運動方程式}

前節に述へたように，操舵による運動では pivoting point の位置は急激に変化しないことに着目すると，船 


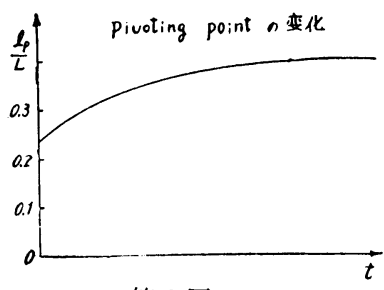

第 3 図
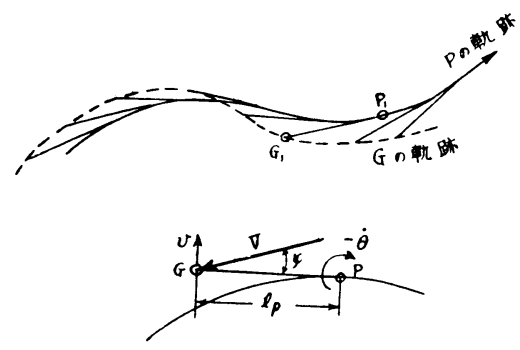

第 4 図

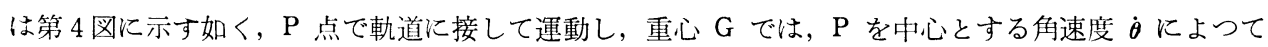

$$
v=-l_{p} \dot{\theta}
$$

なる drift を生じていることになる。即ち（1）式の第 2 式に入つている横すべり速度 $v$ は，勝手な值を取る のではなくて，(6) 式によつて $\dot{\theta}$ と結びつけられているのである。

(6) 式の関係を (1) 式第 2 式に入れると

$$
\frac{d \dot{\theta}}{d t}=\left(-f_{1} l_{p}+f_{2}\right) \dot{\theta}+k_{n} \cdot \delta
$$

となる。これは $\dot{\theta}$ の1次系表示に外ならないのであつて，これを変形して

と書き, 野本氏の 1 次系近似式

$$
\frac{1}{f_{1} l_{p}-f_{2}} \frac{d \dot{\theta}}{d t}+\dot{\theta}=\frac{k_{n} \cdot \delta}{f_{1} l_{p}-f_{2}}
$$

$$
T \frac{d \dot{\theta}}{d t}+\dot{\theta}=K \delta
$$

と比較すると

$$
\left.\begin{array}{l}
T=1 /\left(f_{1} l_{p}-f_{2}\right) \\
K=k_{\gamma z} /\left(f_{1} l_{p}-f_{2}\right)
\end{array}\right\}
$$

となる。(8) 式は近似式ではないから， $T, K$ も近似ではないが， $l_{p}$ が角速度によつて变わることと，係数 $f_{1}, f_{2}$ 等が変化するので角速度乃至舵角によつて変化することが予想される。

一方，(9）式より $T$ と $K$ の間には

$$
K / T=k_{\imath 3}
$$

という極めて簡単な関係が存在する。しかるに $k_{n}$ は $(1)$ 式に示す如く， $k_{n} \cdot \delta=$ 舵のモーメント/ I $+T_{z}$ であ. るから船型と舵の大きさ及び形で定まる。即ち

舵の垂直力 $=1 / 2 \rho C_{n} A V^{2}$

(ただし $C_{n}$ は船後の舵の垂直力係数) $\overline{G R}=$ 重心より舵の圧力中心迄の距離， $\rho$ は水の密度とすると

$$
K / T=k_{n}=\frac{1 / 2 \rho C_{n b} A V^{2} G R \operatorname{Cos} \delta}{\left(I_{z}+J_{z}\right) \delta}=\frac{1 / 2 \rho \cdot g}{W / L^{2} d} \cdot \frac{C_{n}}{\delta} \cdot \frac{A}{L \cdot d} \cdot \frac{G R / L}{(\kappa / L)^{2}} \cdot \frac{V^{2}}{L^{2}} \operatorname{Cos} \delta
$$

となり， $k_{n}$ は船の肥㾑度，見掛質量を含む慣動半径，舵面積比，及び速度と船長の比の二乗に関係する。しか しながらこれらの量は角速度には無関係であるから， $K$ と $T$ は非線型影響によつて角速度によつて变つても， その比は変化しないことが判る。

（11）式は，見掛質量を含む慣動半径 $\kappa / L$ の值が現在余り正確には求められていない外は相当の精度で推定 しらるから, 結局 $K$ と $T$ の内何れか 1 つが判れば他の 1 つは求められるわけである。

(11) 式の精度を調べるために, 野本氏 ${ }^{(4)}$ の求めた実験的な $T$ と $K$ の関係と比較して見ると第 1 表の如く なる。

ただし $T^{\prime}, K^{\prime}$ は $T$ 及び $K$ を無次元化せるもので，計算に当つては $\kappa / L を ~ 1 / 3, C_{n} / \delta=2.05 / \mathrm{rad}$ としある。

第1表を見ると Tanker 及び Freighter ではよく合つているが，whaler ではかなり違つている。これは主 として $\kappa / L$ の值の相異によるものと考兄られ，船型別の $\kappa / L$ の值が実験的に求められれば精度はずつと向上す るものと思われる。 
第 1 表

\begin{tabular}{l|l|l}
\hline \multicolumn{1}{c|}{ 船 } & $K^{\prime} / T^{\prime}\left(z^{\text {試験より) }}\right.$ & $K^{\prime} / T^{\prime}((11)$ 式より) \\
\hline Tanker (full) & 0.572 & 0.568 \\
Tanker (ballast) & 1.47 & 1.21 \\
Tanker & 0.573 & 0.646 \\
Freighter & 0.788 & 0.838 \\
Freighter & 1.22 & 1.47 \\
Freighter & 1.57 & 1.43 \\
Freighter & 1.39 & 1.51 \\
Bulk-Carrier & 1.03 & 1.37 \\
Fish Carrier & 1.77 & 1.91 \\
Whaler & 1.32 & 2.83 \\
Whaler & 1.37 & 1.96 \\
Whaler & 0.922 & 1.88 \\
\hline
\end{tabular}

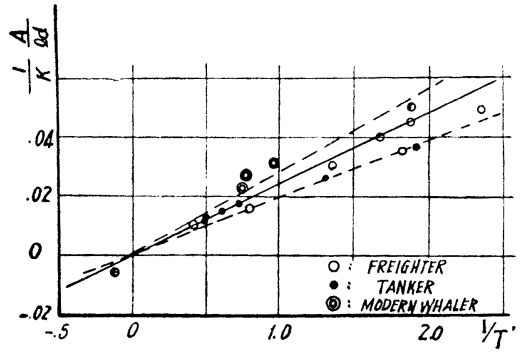

第 5 図

を対比したもので，2つの破線が（11）式で $\kappa / L$ を $1 / 3$ 及び $1 / 2.5$ としたものである。

従来旋回性と保針性とは相反するものであることが経験的に知られていたが，(10) 式，(11）式はこの関係を 明確に表わしたもので, 明らかに旋回性と保針性は反比例し，その比例常数が $k_{n}$ であること，及びその比例常 数は船型及び舵の面積比, 舵角によつて変化するものであることが判る。

高橋, 川島両氏 (7)によれば, 操舵直後の角度の変化即ち舵の効き（両氏はこれを追随性と言つているうは $K / T$ (同論文中では $-K \cdot p)$ に等しいから, 操舵直後の舵の効きは $k_{n}$ であり，やはり舵面積及び船型によつて 11) 式の如く変化することが判る。

\section{2 定常旋回による操縦性指数の決定}

(9) 式に抢いて $f_{1}, f_{2}, l_{p}$. 等は水槽試験で求める事も出来るが，大角度の操舵の場合には角速度によつて变 化するので，（8）式及び（10）式の関係を用いて実験的に求める方法を考えてみる。

そこで種々の試験方法が考光られるが最も基本的な操縦運動である定常旋回上り $K$ と $T$ を求めるのが一番 便判であろう。

(8) 式を書き直して

$$
T_{s} \frac{d \dot{\theta}}{d t}+\dot{\theta}=K_{s} \delta
$$

とすると，定常旋回では $d \dot{\theta} / d t=0$ であるから

$$
\dot{\theta}_{s}=K_{s} \cdot \delta, \quad K_{s}=\dot{\theta}_{s} / \delta
$$

即ち旋回性指数 $K_{s}(s$ とい添字は定常旋回を表わす) は，定常旋回の角速度 $\dot{\theta} s$ を舵角で割つたものに等し W。

また旋回半径 $R$ は $R=V_{s} / \dot{\theta}_{s}$ であるから

$$
K_{s}=V_{s} / R \cdot \delta
$$

無次元化して

追従性指数 $T_{s}$ は，(10) 式より

$$
K_{s}{ }^{\prime}=K_{s} \times L / V_{s}=L / R \cdot \delta
$$

$$
T_{s}=K_{s} / k_{n}=\dot{\theta} s \mid k_{n \imath} \cdot \delta
$$

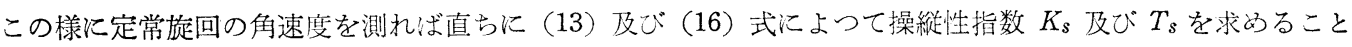
が出来る。第 6 図は巡視船について $K_{s}$ 及び $T_{s}$ を種々の舵角について求めた一例で, 速度の影響を除くため, 無次元表示してある $\left(T_{s^{\prime}}=T_{s} \times V_{s} / L\right)$ 。

第 6 図を見ると $K_{s}{ }^{\prime}, T_{s}{ }^{\prime}$ 共淮速度 (即ち曲率) が増加すると徐々に減少することが判るが，これは $l_{p}$ が前 汇移るためと, $f_{1}, f_{2}$ 等の係数が曲率によつて变化するためである。また図中二重マークで示してあるのは, 野本 氏の方法によつて， $z$ 試験より求めた操縦性指数で岁つて，K'については大き目，1/T'については小さ目に出 ているが，これは $\boldsymbol{z}$ 試験で例えば $20^{\circ}$ の操舵をした場合に船の角速度は最大が定常旋回に等しく，平均はそれ より小さいので, 角速度0ょり $\dot{\theta}_{s}$ 迄の間の $K_{s}$ 及ざ $T_{s}$ を平均した様なるのが出るためである。この事から逆に $z$ 試験より求めた $K$ を用いて定常旋回を表わす場合には，少し小さくする様な修正が必要であることが判る。 また第 6 図中の塗りつぶした点は，(13）式の角速度として， $z$ 試験の最大角速度を取つたもので, 殆んど定常 


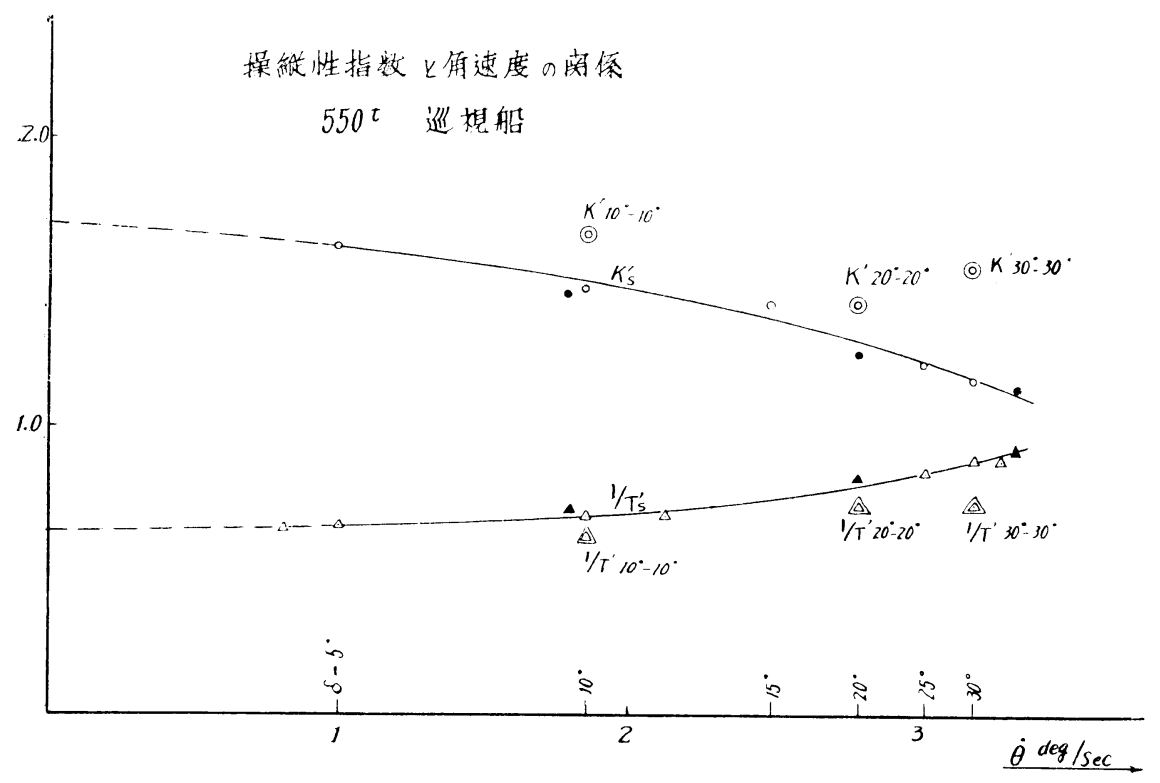

第 6 図

预回と同じ結果を与える。

結局 $K, T$ と $K_{s}, T s$ の違いは, 前者が或る角 涑度の範围の平均值であり, 後者は或る角速度に 対する候であるということである。

第 7 図は同様に $500 \mathrm{G}, \mathrm{T}$ の客船について求め たもので $K, T$ と $K^{\prime}, T^{\prime}$ との関係及び角速度に よる变化も同栐で, 唯前の船より角速度による変 動が著しい。

第 2 表は文献 (8)の $z$ 試験より求められた $K^{\prime}$ と $T^{\prime}$ に対し, 同じ船の旋回試験の資料を用いて, （15）及び (16) 式によつて $K_{s}{ }^{\prime}$ 及び $T^{\prime}$ を求 わて比較したものである。

第 2 表を見ると $K^{\prime} / T^{\prime}$ と $K_{s}{ }^{\prime} \mid T_{s}{ }^{\prime}$ はよく合つ ているが， $K^{\prime}$ と $K_{s^{\prime}}, T^{\prime}$ と $T_{s^{\prime}}$ とは多少違つて

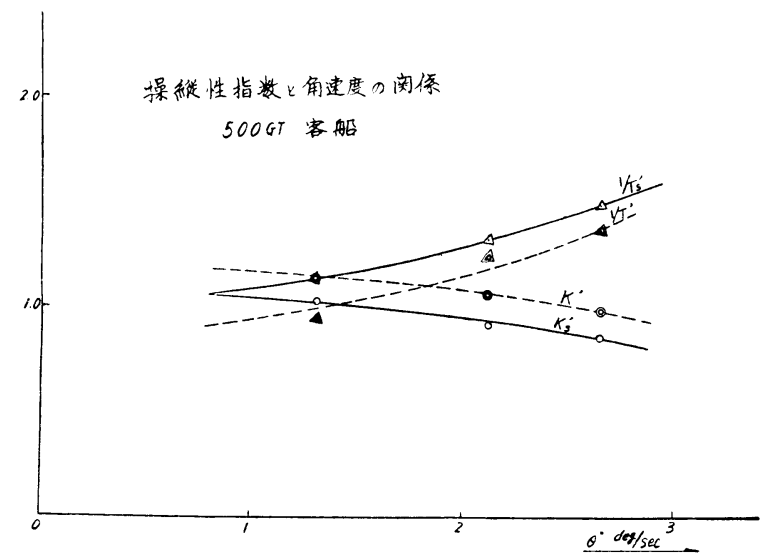

第 7 戍 抢り，やはり第 6,7 図と同じく, $z$ 試験より求めたものの方が大きく出ていることが判る。

第 2 表

\begin{tabular}{|c|c|c|c|c|c|c|c|c|c|c|}
\hline \multirow{2}{*}{ 船 } & \multirow{2}{*}{ 種 } & \multicolumn{3}{|c|}{$\boldsymbol{z}$ 試 験 よ り } & \multirow[b]{2}{*}{$R_{\text {port }}$} & \multirow{2}{*}{$\begin{array}{l}\text { 旋 } \\
R_{\text {stb. }} .\end{array}$} & \multirow{2}{*}{$\begin{array}{l}\text { 回 試 } \\
R_{\text {mean }}\end{array}$} & \multirow{2}{*}{$\begin{array}{l}\text { 験 よ } \\
K_{s^{\prime}} \\
\end{array}$} & \multicolumn{2}{|l|}{ b } \\
\hline & & $K^{\prime}$ & $-b^{\prime}=1 / T^{\prime}$ & $K^{\prime} / \boldsymbol{T}^{\prime}$ & & & & & $1 / T_{s^{\prime}}$ & $K_{s^{\prime}} / T_{s^{\prime}}$ \\
\hline & & 1.095 & 0.625 & 0.788 & $274 \mathrm{~m}$ & $255 \mathrm{~m}$ & $265 \mathrm{~m}$ & 1.033 & 0.702 & 0.727 \\
\hline & & 0.823 & 1.760 & 1.450 & 205 & 1.95 & 200 & 1.083 & 1.490 & 1.610 \\
\hline & & 1.175 & 0.508 & 0.597 & 250 & 260 & 255 & 1.160 & 0.556 & 0.646 \\
\hline & & 1.200 & 0.497 & 0.596 & 372 & - & 372 & 0.884 & 0.687 & 0.579 \\
\hline & & 1.000 & 0.788 & 0.788 & 315 & 290 & 298 & 0.797 & 1.10 & 0.878 \\
\hline
\end{tabular}

なお操縱性指数を求めるための旋回試験としては, 航跡を取る必要はなく, 時間対回頭角度及び前進速度の変

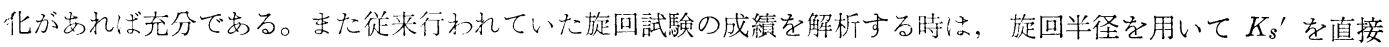
求めるのが適当であろう。

\section{3 解の形と $K_{s}, T_{s}$ の意味}

(12) 式を解くと解は極めて簡単な形となり 


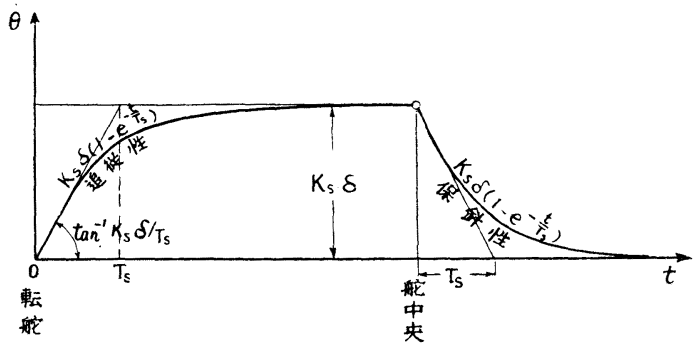

$$
\begin{array}{r}
t=0 \text { で } \dot{\theta}=0 \text { とすると } \\
\dot{\theta}=K_{s} \delta\left(1-e^{-{ }^{t}} T_{\boldsymbol{s}}\right)
\end{array}
$$

即ち第 8 図に示す様に, 終端角速度 $K_{s} \delta=\dot{\theta} s$ に向つて 指数函数で収斂する曲線となる。また原点の切線の $\tan$ は $K_{s} \delta . / T_{s}$ となり, 切線と $\dot{\theta}=K \delta$ との交点に相 当する時間は $T_{s}$ となるから， $T_{s}$ は事害上，運動が 定常に達する迄の時間を示す尺度となる。

また（17）を積分して

$$
\theta=K_{s} \cdot \delta t-K_{s} \cdot \delta \cdot T_{s}\left(1-e^{-\frac{t}{T_{s}}}\right)
$$

で回頭角が出るが，極く初期の回頭角度は

$$
\theta=\frac{1}{2} \ddot{\theta}_{0} t^{2}=\frac{1}{2}\left(K_{s} \delta / T_{s}\right) t^{2}
$$

となり，初期の回頭角の大小，即ち舵の効きは $\left.K_{s} \delta\right]^{\prime}$ $T_{s}$ で表わされる。即ち，

$$
\text { 舵の効き } \propto K_{s} \delta / T_{s}=k_{n} \cdot \delta
$$

これは高橋, 川島画氏(7)の追随性 $K \cdot p$ 亿相当する。 定常旋回中に急に舵を中央に戻すと，後に 5 で述べ る如く，舵中央に対する pivoting point の位瓃が操 第 8 図 舵の時より前に智るため， $T_{s}$ は保針性指数 $T_{1}$ へ移

つてゆき，

$$
\begin{aligned}
& \dot{\theta}=K_{s} \cdot \delta\left(e^{-\frac{t}{T_{1}}}\right) \\
& \theta=\theta_{0}+K_{s} \delta T_{1}\left(1-e^{-\frac{t}{T_{1}}}\right)
\end{aligned}
$$

となるから，舵を中央に戻してから最後に向く方向は

$$
\Delta \theta=K_{s} \delta T_{1}
$$

となる。しかしながら pivoting point の位置は舵を中央に戻しても直らに移動するわけでなく，従つて $T_{s} も$ $T_{1}$ に直ちに移動しないので， $\Delta \theta$ は $K_{s} \delta T_{s}$ と $K_{s} \delta T_{1}$ の中間位となると見るべきである

第 9 図は巡視について実際に第 8 困に相当する操舵をした結果と，Ks, $T_{s}$ を用いて $(17) \sim(22)$ 式で計算した 值とを比較したものである。

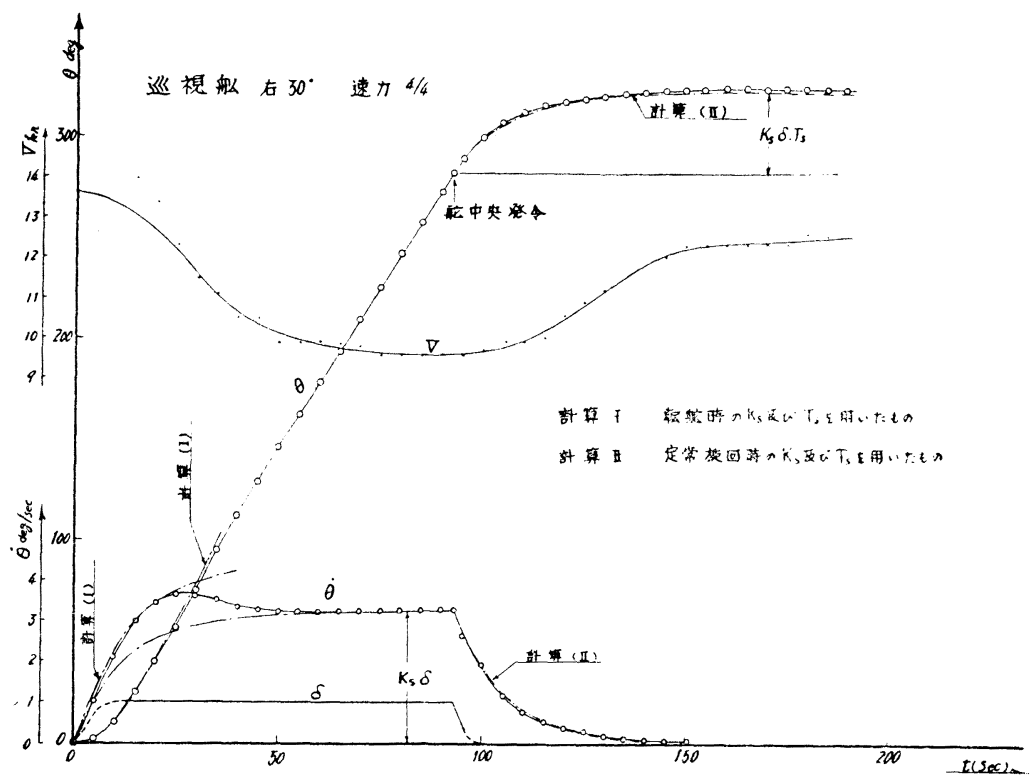

第 9 図 
旋回初期を除いてはかなりよく一致することが判る。旋回初 期では速度変化が大さいために，定常旋回の $T_{s}, K_{s}$ をそのま ま用いたのではよく合わないが，速度の修正をすればよく一致 する。しかしながら旋回初期を $K_{s}, T_{s}$ を用いて表わすのは現 在の目的ではないので詳述は省く。

舵を中央に戻した時からの回頭角は計算と極めてょく一致し ている様に見える。

なお゙，多くの船の回頭角度曲線は第 9 図の如く上に向つて凸 になる傾向があり，従つて角速度も定常に達する前に山を生じ るが，これは第 10 図に示す様に，船の前進速度は極めてゆる やかに減少するのに対して，旋回の角速度はかなり早く追従す るので，最初かなり高い速度に対する $K$ 及び $T$ の值で角速 度が增加するが，速度が徐々に減少すると共に $K$ 及び $T$ の 值も徐々に変化してゆくためである。しかし航跡の方は前進速 度では大して変化しないので, 角速度が極大になる時間より先 は事実上真円となる。

第 11 図は巡視船の $z$ 試験の結果を定常旋回より求めた $K_{s}$

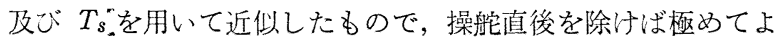
<一致する。

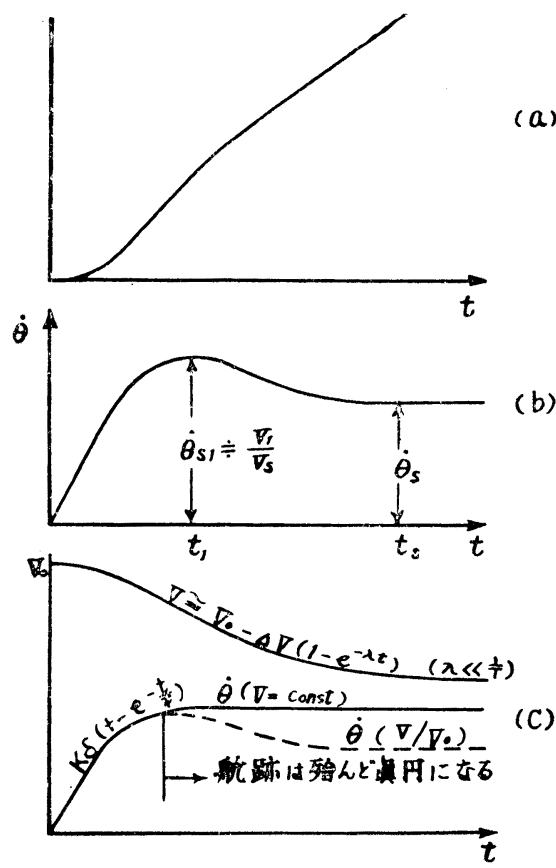

第 10 図

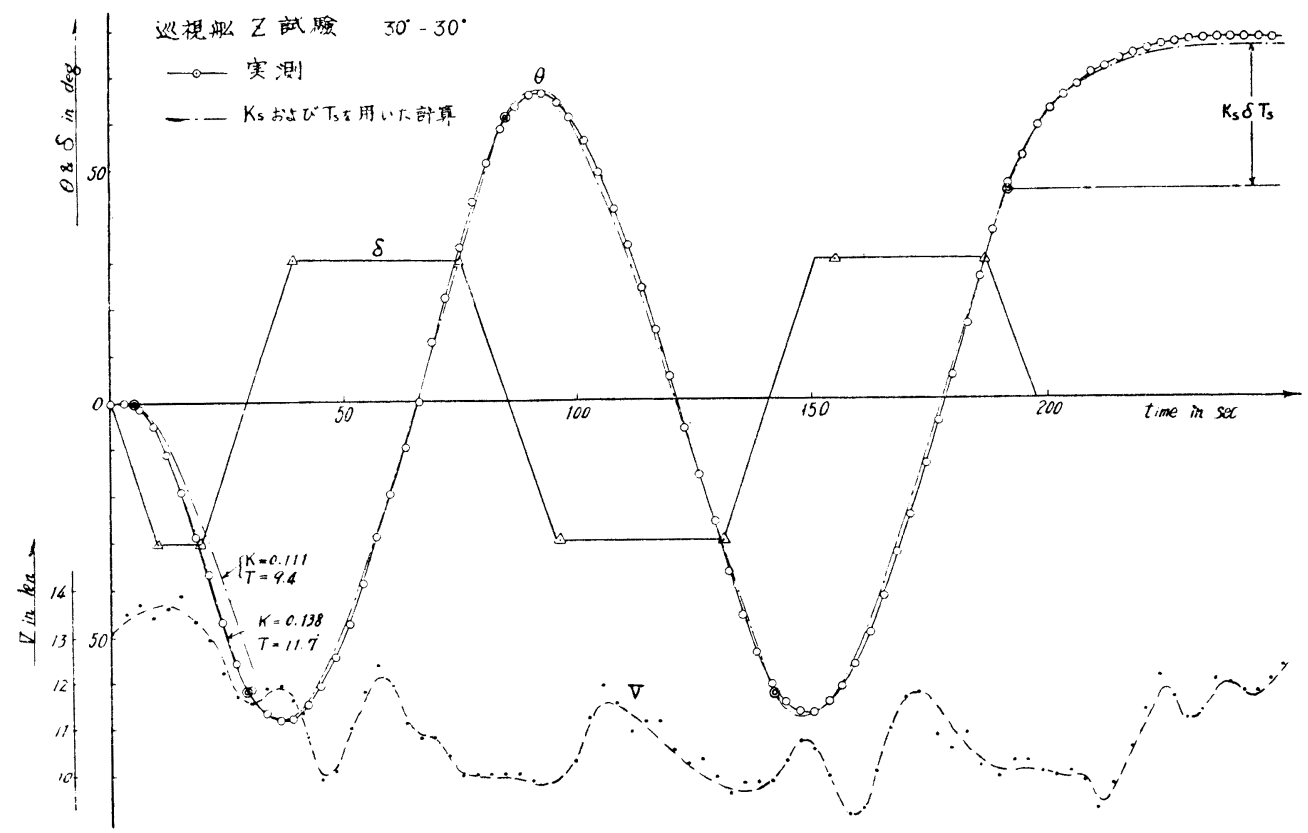

第 11 図

\section{4 前進速度 の 影響}

操縦性指数は

$$
\begin{aligned}
K_{s}{ }^{\prime} & =K_{s} \times L / V \\
T_{s}{ }^{\prime} & =T_{s} \times V / L
\end{aligned}
$$

汇よて無次元化することが出来るが，果して無次元化したものが速度に無関係になるかどらかる確かめるため 


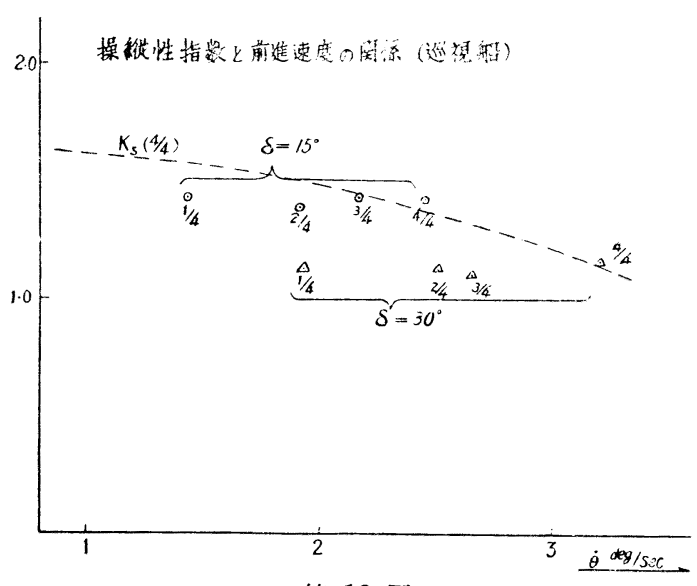

第 12 図
に, 巡視船について, 舵角 $15^{\circ}$ 及び $30^{\circ}$ の場合に つき前進速度を 4 種類に変えて試験を行つた。その 結果を第 12 四に示す。

第 12 図を見ると, 無次元化したものは確かに速: 度には無間係となり，結局 $K_{s}$ は速度に比例し，

$T_{s}$ は速度に反比例することが判る。

なお 11 図のbase 怯回転角速度であるが，荓一。 舵角即ち同一の旋回円に対する操縱性指数は回転角 速度に無関係に一定であることから，第6，7汹に． 示した $K_{s^{\prime}}{ }^{\prime}, T_{s^{\prime}}{ }^{\prime}$ は旋回角速度によつて変化するの でなく旋回円乃至旋回曲率によつて変化するもので あることが判る。従つて第 6,7 図の base は角速: 度より角舵角に対する旋回曲率, 或いは旋回半径を 取る方が妥当である5。

括

以上述べて来た事を簡単にまとめてみると

（1）旋回運動をその時々の pivoting point の周りの運動と考えることにより1次系表示をすることが出来: る。しかしながら pivoting point は旋回初期には重心に近く，旋回が進むと共に前に移るため，運動を表わす 係数も運動の段階（乃至航跡の曲率の大小）によつて多少変化する。

（2） 2 つの操縦性指数 $K_{s}, T_{s}$ の比 $K_{s} / T_{s}=k_{n 2}$ は船型及び舵によつて定まり，容易に計算出来るから， $K_{s}$, $T_{s}$ の中どちらか一方が実験で求められれば他方は求められる。

(3) $K_{s} / T_{s}=k_{n}$ は亦, 旋回初期化拈ける舵の効きを表わす。

（4）定常旋回の角速度より $\dot{\theta} s=K_{s} \delta$ として $K_{s}$ を求めるのが最も簢単であり，且従来の旋回試験の資料を 用いることが出来る。その結果 $K_{s}$ は旋回性を表わし，定常旋回半径と直接結びつけられる。また $T_{s}$ は追従 性を表わし，1/Ts の大小により追従性の良否がきまる。

(5) $K_{s}, T_{s}$ は速度及び角速度によつて变化するが無次元化したものは曲率のみに関係する。これは $l_{p} の$ 変 化及び非線型影響によるものである。曲率が增す程，旋回性は低下し，追随性は增大する。

（6）定常旋回の $K_{s}, T_{s}$ そのまをを用いて転舵直後からの運動を表わそうとすると, 旋回初期に多少の誤差 を生じるが，速度の修正を行えば殆ど一致する。

（7）定常旋回より求めた $K_{s}, T_{s}$ は或る曲率に対する値を与え， $z$ 試験より求めた $K, T$ は或る曲率の範囲 の平均值となる。そして $K_{s}, T_{s}$ 共に曲率の増大と共に減少するから， $z$ 試験より求めた $K, T$ は常に $K_{s}, T_{\varepsilon}$ よりも大きい。

な稿を結ぶに当り, 実験及び資料の収集に対し種々便宜を与えられた海上保安庁水品技術部長, 梶田邦夫, 田坂鋭一，岩田秀一以下の諸氏並びに野本助教授，川島栄一両氏に対し厚く御礼申上げる次第である。

\section{参考文 献}

（1）元良誠三「航路安定性について」造船協会々報 77 号，1945

(2) K.S. M. Davidson \& L. I. Schiff “Turning and Course-Keeping Qualities” SNAME, V.54, 1946

（3）野本謙作外，「船の操縦性について」（I）造船協会論文集 99 号，1955

（4）同上同上 (II) 同 101 号, 1956

（5）同上 $\Gamma z$ 試験の新解析法」同号 103 号, 1958

（6）同上「大型油槽船の操縱性飞関する模型実験」同 103 号

（7）高橋菊夫，川島栄一，「 $\boldsymbol{z}$ 操舵試験による実船操縱性能の解析とその応用」閔西造船協会誌 88 品 1957

（8）赤崎繁，「船の旋回に関する研究」造船協会ヶ報 61 号 
附録

(1) 式に於て $v=V \sin \psi, \vdots V \psi \quad \dot{\theta}=\dot{\theta}$ と持计ば

$$
V d \psi / d t=k_{1} V \psi+k_{2} \dot{\theta}+k_{p} \delta
$$$$
\left.d \dot{\theta}_{l}^{\prime} d t=f_{1} V \psi+f_{2} \dot{\theta}+k_{r_{3} \delta}\right\}
$$

となる。これは Davidson の下記の運動方程式に相当するものである。

$$
\left.\begin{array}{l}
m^{2} \frac{d \psi}{d t}+\psi C_{0}-\dot{\theta}\left(\begin{array}{c}
l \\
V
\end{array}\right)\left(m_{1}-C f\right)=C_{\lambda}(\delta) \\
d \dot{\theta}\left(\begin{array}{c}
l \\
V
\end{array}\right)^{2}-\psi C m+\dot{\theta}\left(\begin{array}{c}
l \\
V
\end{array}\right) C k=C \mu(\delta)
\end{array}\right\}
$$

(1)と (2)' の間には $\quad-k_{1}=C e / m^{2}, \quad k_{2}=-\left(l / m_{2}\right)\left(m_{1}-C f\right) \quad k_{p} \delta=C_{\lambda}(\delta) V / m_{2}$ $f_{1}=-C m / n \cdot l \quad-f_{2}=C k / n \quad k_{n} \delta=C \mu(\delta) / n$ 